\title{
Conditioning with Lime and Fertilizer Improves Ionic Rare Earth Mine Tailings
}

\author{
Qin Zhang $\mathbb{D}^{D}$, Dongmei Shen $\left(\mathbb{D}\right.$, Jie Luo $\left(\mathbb{D}\right.$, Guanyue Wan $\mathbb{1 D}^{\text {, }}$, Caiyun Zhou $(\mathbb{D}$, \\ and Xiaomin Zhao
}

\begin{abstract}
Key Laboratory of Poyang Lake Watershed Agricultural Resources and Ecology of Jiangxi Province, College of Land Resources and Environment, Jiangxi Agricultural University, Jiangxi Province, Nanchang 330045, China
\end{abstract}

Correspondence should be addressed to Xiaomin Zhao; zhaoxm889@126.com

Received 9 September 2021; Accepted 5 November 2021; Published 22 November 2021

Academic Editor: Qiaohui Fan

Copyright (c) 2021 Qin Zhang et al. This is an open access article distributed under the Creative Commons Attribution License, which permits unrestricted use, distribution, and reproduction in any medium, provided the original work is properly cited.

\begin{abstract}
To explore rare earth mine tailings improvement technology without soil dressing, we planted Chinese cabbage in pots to determine the effect of different amounts of lime combined with fertilizer on the improvement of ionic rare earth mine tailings, aiming to provide a scientific basis for the reclamation of abandoned ionic rare earth mines. The results showed that the soil substrate of the tested rare earth tailings exhibited four forms of degradation: soil acidification, soil desertification, nutrient depletion, and heavy metal contamination by rare earth elements (REEs). The application of fertilizer alone (CK treatment) did not support Chinese cabbage growth, whereas different amounts of lime combined with fertilizer supported plant growth and significantly reduced the activity of the rare earth heavy metals. The height, fresh weight, and REE content of the Chinese cabbage plants were significantly reduced with an increase in the amount of lime applied. Addition of lime not only significantly improved the soil pore space and reduced soil acidification but also significantly increased the soil nutrient content. Our findings suggest that lime combined with fertilizer can improve ionic rare earth mine tailing soil degradation, thus promoting plant growth and achieving the improvement of ionic rare earth mine tailings without soil dressing.
\end{abstract}

\section{Introduction}

Rare earth elements (REEs) are widely used in various national economy fields. In particular, heavy REEs are crucial to the development of high-tech industries, modernization, and national defense [1]. As the main source of heavy RREs, ionic rare earth ores are minerals in which REEs are adsorbed on the weathering crust of granite in an ionic form, and their mining requires the use of a leaching agent containing a large number of chemically active cations $\left(\mathrm{Na}^{+}\right.$, $\mathrm{NH}_{4}^{+}, \mathrm{H}^{+}$, and $\mathrm{Mg}^{2+}$ ) to replace and desorb the ionic REEs [2]. This unique mining process leads to differing degrees of contamination of soil and water resources in mining areas, and pollutants can migrate through the water and soil into the food chain, eventually becoming hazardous to human health [3-5]. The ecological restoration of ionic rare earth mining areas in China is imminent $[6,7]$.
Ionic rare earth mining areas exhibit soil degradation of types that are difficult to restore, including soil desertification, soil nutrient decline, soil acidification, heavy metal contamination, and leaching agent residues $[8,9]$. Presently, the restoration of rare earth mine tailings adopts a soil dressing approach; however, the soil dressing method requires a large number of soil resources at a high cost. Therefore, it is particularly important to investigate other restoration and improvement methods that do not require soil dressing for reclamation of ionic rare earth mine tailings. Soil conditioner is an efficient and inexpensive restoration and improvement method, and the application of soil conditioner can improve soil $\mathrm{pH}$, reduce heavy metal activity, and improve soil structure [10]. For many types of soil degradation, different soil amendments can be used in combination to enhance the restoration effect, which is a major measure of soil ecological restoration in mining areas [11, 
12]. To date, little research has been conducted on methods to improve the soil substrate of ionic rare earth mine tailings. The effect and mechanism of inorganic conditioners on the improvement of ionic rare earth mine tailings have been rarely studied. Lime, when used as a common soil conditioner, can regulate soil acidification and reduce the heavy metal activity of soils, whereas $\mathrm{Ca}^{2+}$ ions as a cementing agent facilitate the formation of soil aggregates, thus reducing soil desertification $[13,14]$. The application of fertilizers can rapidly increase soil nutrients and improve soil nutrient depletion.

An understanding of the effects of lime combined with fertilizer on cabbage growth and on the physicochemical properties of the rare earth tailings is urgently required in order to determine whether this method can effectively the degradation problem of rare earth tailings. Once the method works, a more reasonable amount of lime and fertilizer should be furtherly determined. The central hypotheses of our study were as follows: (1) the application of conditioner could mitigate the problem of soil degradation of ionic rare earth mine tailings, such as reducing soil desertification and acidification; (2) the treatments conditioned with a combination of fertilizer and lime could greatly improve the growth of cabbage. The results could provide a theoretical basis for soil improvement and restoration in ionic rare earth mining areas.

\section{Materials and Methods}

2.1. Rare Earth Tailings. Rare earth tailings were collected from an abandoned rare earth mine $\left(25^{\circ} 27^{\prime} \mathrm{N}, 115^{\circ} 10^{\prime} \mathrm{E}\right)$ in Xinfeng County, Ganzhou, Jiangxi Province, which had been closed for 1 year and mined using the heap leaching process. The ammonium sulfate $\left(\left(\mathrm{NH}_{4}\right)_{2} \mathrm{SO}_{4}\right)$ was employed as the leaching agent, producing high ammonium sulfate residue in tailing [15]. The tailings were sampled at a depth of $0-$ $20 \mathrm{~cm}$ and bagged and sealed after mixed sampling from five points close to the mine. The sampling time was May 15, 2016. The tailing samples were laid flat on the ground to form a soil layer approximately $10 \mathrm{~cm}$ thick, air-dried for 15 days, and then fully mixed by five turnings of the heap and rebagged for use in the experiment. The basic physicochemical properties of the rare earth tailings are presented in Tables 1 and 2.

2.2. Experimental Design. The experiment was conducted in pots under simulated natural conditions. The plastic pots used in the experiment had an upper inner diameter, lower inner diameter, and height of $17.5,11.5$, and $12 \mathrm{~cm}$, respectively, and each pot was filled with $1.8 \mathrm{~kg}$ of air-dried tailings passed through a $2 \mathrm{~mm}$ sieve. Lime combined with fertilizer was used as the conditioner to improve the rare earth tailings, with the same amount of fertilizer but different amounts of lime applied to all treatments. The fertilizer was applied once as a base fertilizer at concentrations of $0.20 \mathrm{~g} \mathrm{~N}$ (i.e., $0.428 \mathrm{~g} / \mathrm{kg}$ urea), $0.30 \mathrm{~g} \mathrm{P}_{2} \mathrm{O}_{5}$ (i.e., $0.575 \mathrm{~g} / \mathrm{kg}$ monopotassium phosphate), and $0.30 \mathrm{~g} \mathrm{~K}_{2} \mathrm{O}$ (i.e., $0.161 \mathrm{~g} /$ $\mathrm{kg}$ potassium chloride) per $\mathrm{kg}$ of tailings. There were four treatments in the experiment: CK for fertilizer application only, C1 for fertilizer $+10 \mathrm{~g} / \mathrm{kg}$ lime, C2 for fertilizer $+25 \mathrm{~g} /$ $\mathrm{kg}$ lime, and C3 for fertilizer $+50 \mathrm{~g} / \mathrm{kg}$ lime, with four replications for each treatment. Following fertilization, ultrapure water was applied to the soil in each treatment pot to maintain a field water holding capacity of $70 \%$. After three weeks of stable incubation of the soil, ten Chinese cabbage seeds were sown in each pot after immersion of the seeds in warm water $\left(50^{\circ} \mathrm{C}\right)$. The pots were watered every $2-3$ days throughout the growth process, and the cabbages were harvested after 140 days of growth.

2.3. Sample Collection and Analysis. At the time of harvest, the Chinese cabbage plants were uprooted and rinsed with water. Three plants were randomly selected from each pot for determination of their fresh weight. Thereafter, the samples were placed in an oven at $105^{\circ} \mathrm{C}$ for $30 \mathrm{~min}$, dried at $75^{\circ} \mathrm{C}$ to a constant weight, and then milled and bagged. The tailing samples were collected from the pots after the cabbage harvest. They were dried naturally, ground using the quartering method, and passed through first a 20-mesh $(0.841 \mathrm{~mm})$ sieve, then a 100 -mesh $(0.147 \mathrm{~mm})$ nylon sieve. The tailings texture, $\mathrm{pH}$ value, soil organic matter content, soil available $\mathrm{N}$, soil available $\mathrm{P}$, and soil available $\mathrm{K}$ were determined using the hydrometer method, potentiometric method (soil: water $=1: 2.5$ ), potassium dichromate volumetric method, alkaline diffusion method, sodium bicarbonate method, and ammonium acetate extraction method, respectively. Total $\mathrm{N}$ was determined using the Kjeldahl method, and total $\mathrm{P}$ and total $\mathrm{K}$ were determined using the sodium hydroxide fusion method. Both the plant and soil samples were digested using the four-acid method ( $\mathrm{HCl}-$ $\mathrm{HNO}_{3}-\mathrm{HF}-\mathrm{HClO}_{4}$ ), and the amount of each of 16 REEs was determined by inductively coupled plasma mass spectrometry (ICP-MS). The total REE content of the soil was determined from the sum of the amount of each of the 16 REEs ( $\Sigma$ REEs). The amounts of the heavy metals As and $\mathrm{Cd}$ in the soil were determined using an atomic fluorescence spectrometer (AFS) and graphite furnace atomic absorption spectrometry (GF-AAS), respectively, whereas the contents of the other five heavy metals $(\mathrm{Pb}, \mathrm{Cr}, \mathrm{Cu}, \mathrm{Ni}$, and $\mathrm{Zn}$ ) were determined by an inductively coupled plasma optical emission spectrometer (ICP-OES).

2.4. Statistical Analysis. OriginPro 2015 and SPSS Statistics 22 were used to process the data for analysis, and analysis of variance of the data was performed using the LSD method, with different lowercase and uppercase letters in the same column indicating significant $(P<0.05)$ and highly significant $(P<0.01)$ differences among treatments, respectively.

\section{Results}

3.1. Basic Physicochemical Properties of the Soil Substrate of Rare Earth Tailings. The basic physicochemical properties of the soil substrate of the tested rare earth tailings are presented in Table 1. The $\mathrm{pH}$ of less than 4.5 indicated a strongly acidic soil and showed that the rare earth mining led to severe soil acidification. The soil substrate contained 
TABLE 1: Basic physical and chemical properties of the soil substrate in rare earth mine tailings.

\begin{tabular}{ccccccccccc}
\hline Sample & $\mathrm{pH}$ & $\begin{array}{c}\text { Available N } \\
(\mathrm{mg} / \mathrm{kg})\end{array}$ & $\begin{array}{c}\text { Available P } \\
(\mathrm{mg} / \mathrm{kg})\end{array}$ & $\begin{array}{c}\text { Available K } \\
(\mathrm{mg} / \mathrm{kg})\end{array}$ & $\begin{array}{c}\text { Total N } \\
(\mathrm{g} / \mathrm{kg})\end{array}$ & $\begin{array}{c}\text { Total P } \\
(\mathrm{g} / \mathrm{kg})\end{array}$ & $\begin{array}{c}\text { Total K } \\
(\mathrm{g} / \mathrm{kg})\end{array}$ & $\begin{array}{c}\text { Organic matter } \\
(\mathrm{g} / \mathrm{kg})\end{array}$ & $\begin{array}{c}\text { Clay } \\
(\%)\end{array}$ & $\begin{array}{c}\text { Soil } \\
\text { texture }\end{array}$ \\
\hline Tailing & 4.43 & 151.60 & 2.57 & 44.60 & 0.30 & 0.49 & 31.20 & 1.95 & 6 & $\begin{array}{c}\text { Sandy } \\
\text { loam }\end{array}$ \\
\hline
\end{tabular}

TABLE 2: The heavy metal content of the soil substrate in rare earth mine tailings $(\mathrm{mg} / \mathrm{kg})$.

\begin{tabular}{lcccccccccccc}
\hline & $\mathrm{Cd}$ & $\mathrm{As}$ & $\mathrm{Pb}$ & $\mathrm{Cr}$ & $\mathrm{Cu}$ & $\mathrm{Ni}$ & $\mathrm{Zn}$ & $\Sigma \mathrm{REEs}$ & $\mathrm{La}$ & $\mathrm{Ce}$ & $\mathrm{Nd}$ & $\mathrm{Y}$ \\
\hline Tailing & 0.49 & 24.83 & 50.40 & 52.64 & 47.86 & 14.12 & 120.23 & 673.13 & 96.69 & 224.78 & 105.02 & 95.24 \\
Risk screening values $^{\mathrm{a}}$ & 0.3 & 40 & 70 & 150 & 50 & 60 & 200 & - & - & - & - & - \\
Risk intervention values $^{\mathrm{a}}$ & 1.5 & 200 & 400 & 800 & - & - & - & - & - & - & - & - \\
\hline
\end{tabular}

${ }^{\mathrm{a}}$ Risk control standard for soil contamination of agricultural land (GB15618-2018) $\mathbb{\bigotimes}^{\mathrm{b}}$-_" no standard values.

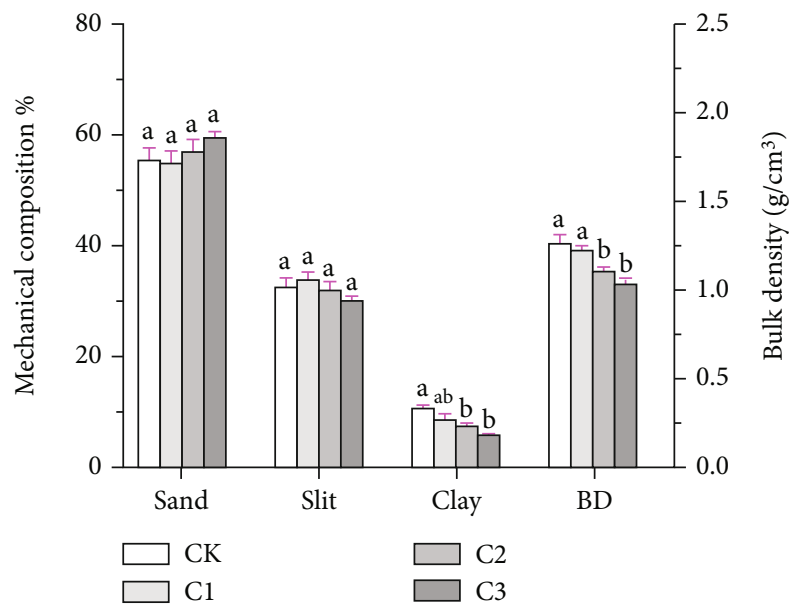

FIGURE 1: Effect of lime combined with fertilizer on soil texture and bulk density of rare earth mine tailings.

high levels of available $\mathrm{N}$ and total $\mathrm{K}$, but relatively deficient and deficient levels of total $\mathrm{P}$ and available $\mathrm{K}$, respectively, whereas organic matter content, available $\mathrm{P}$, and total $\mathrm{N}$ were all highly deficient. These results indicated that different nutrients in the soil substrate of the rare earth tailings occurred in different amounts, but overall, there was a deficiency of nutrients. The extremely high available $\mathrm{N}$ content was most likely due to the use of ammonium sulfate as a leaching agent during the rare earth mining process, which may have resulted in an accumulation of ammonium ions in the tailings soil. The extremely high total $\mathrm{K}$ content was most likely related to the large amount of granite contained in the ionic rare earth mine tailings. In addition, the physical clay content in the soil substrate was very low, and the soil texture was extremely sandy.

The heavy metal contents of the rare earth tailings are presented in Table 2. With the exception of $\mathrm{Cd}$, the concentrations of the other six heavy metals were lower than the risk screening value, indicating that the risk of soil contamination by these six heavy metals was low. The soil Cd concentration was higher than the risk screening value but much lower than the risk control value, indicating that the risk of Cd contamination was also low. Of concern is the high content of REEs in the rare earth tailings, at 2.77 times that of the background values in the soil environment in Jiangxi Province $(243.41 \mathrm{mg} / \mathrm{kg}$ ) [16]. Four elements, Y, La, $\mathrm{Ce}$, and $\mathrm{Nd}$, had high concentrations, the sum of which accounted for $77.51 \%$ of the total amount of RREs in the tailings; therefore, we focused on the total amount of rare earths and the concentrations of these four REEs. In rare earth tailings, in contrast to general contaminated soil, rare earth element contamination must be examined in addition to contamination by common heavy metals. Overall, the substrate of rare earth tailings shows severe acidification, soil desertification, severe nutrient deficiency, and a high content of rare earth-like heavy metals.

\subsection{Physicochemical Properties of Tailings after Conditioning with Lime and Fertilizer}

3.2.1. Effects on Texture and Bulk Density. The effects of soil conditioning using lime combined with fertilizer on the physical properties of the tailings are shown in Figure 1. There was no significant difference in sand and powder content among the treatments, but there was a significant difference in clay content $(P<0.05)$. Compared to the $\mathrm{CK}$ treatment, the soils treated with lime combined with fertilizer all showed a significant reduction in clay content, with a decrease of $19.9 \%, 31.6 \%$, and $45.7 \%$ in treatments $\mathrm{C} 1$, $\mathrm{C} 2$, and $\mathrm{C} 3$, respectively. The soil texture of the control was sandy loam. All the soils conditioned with lime and fertilizer also had a sandy loam texture, indicating that, although there was a statistically significant difference in clay content, it had no significant effect on soil texture. There was a significant difference $(P<0.05)$ in bulk density among the treatments where treatments $\mathrm{C} 2$ and $\mathrm{C} 3$ had a significantly lower bulk density compared to that of the CK treatment; the bulk density of treatments $\mathrm{C} 1, \mathrm{C} 2$, and C3 was lower by $3.17 \%, 12.70 \%$, and $18.25 \%$, respectively. This indicated that lime application significantly improved the soil pore space although it had no significant effect on mechanical composition.

3.2.2. Effects on $p H$ and Organic Matter. The effect of lime combined with fertilizer on soil $\mathrm{pH}$ is shown in Figure 2. There was a highly significant difference in $\mathrm{pH}$ among the 

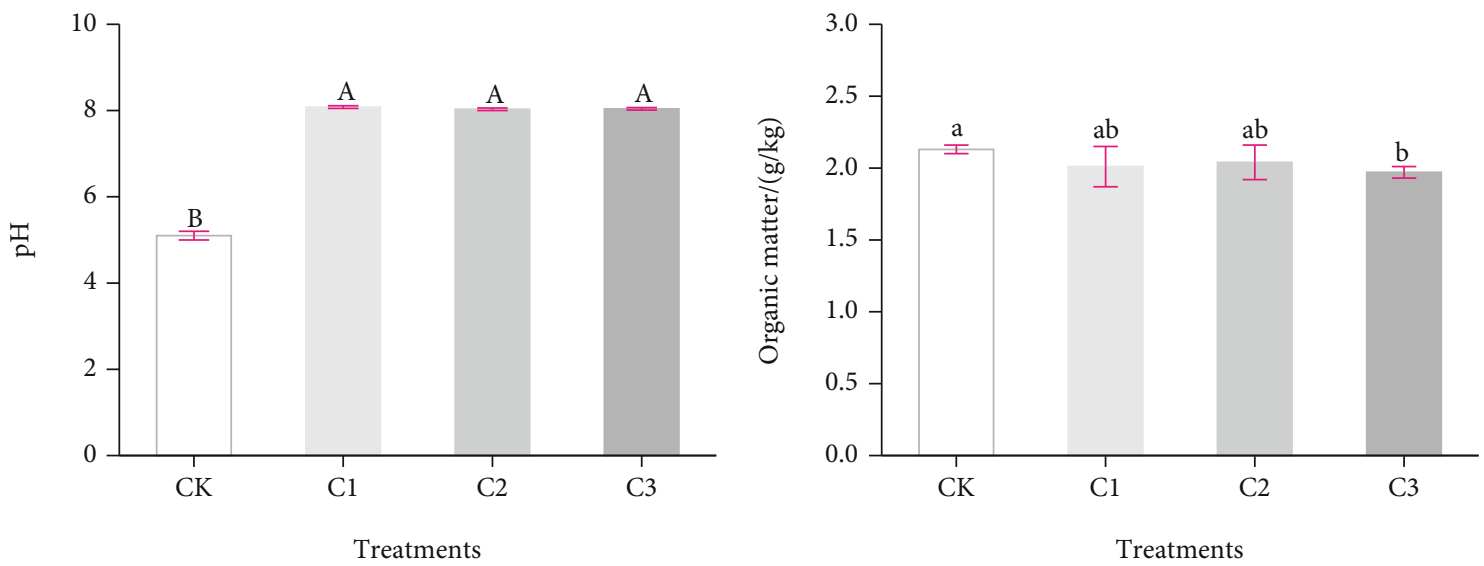

FIGURE 2: Effect of lime combined with fertilizer on soil $\mathrm{pH}$ and organic matter of rare earth mine tailings. CK: fertilizer $(0.20 \mathrm{~g} \mathrm{~N}, 0.30 \mathrm{~g}$ $\mathrm{P}_{2} \mathrm{O}_{5}$, and $0.30 \mathrm{~g} \mathrm{~K} 2 \mathrm{O}$ per $\mathrm{kg}$ of tailings); $\mathrm{C} 1$ : fertilizer $+10 \mathrm{~g} / \mathrm{kg}$ lime; $\mathrm{C} 2$ : fertilizer $+25 \mathrm{~g} / \mathrm{kg}$ lime, and C3: fertilizer $+50 \mathrm{~g} / \mathrm{kg}$ lime.

treatments $(P<0.01)$. Compared to that of the $\mathrm{CK}$ treatment, the $\mathrm{pH}$ was significantly higher in all treatments conditioned with lime and fertilizer, showing substantial increases of 2.99, 2.93, and 2.94 units in treatments C1, C2, and C3, respectively; however, there was no significant difference in soil $\mathrm{pH}$ among these treatments. Significant differences in organic matter content among the treatments were found $(P<0.05)$. The organic matter content in treatment C3 soil was significantly lower compared to that in the CK treatment soil, with reductions of $5.63 \%, 4.23 \%$, and $7.51 \%$ in treatments $\mathrm{C} 1, \mathrm{C} 2$, and $\mathrm{C} 3$, respectively. When the concentration of added lime was low (treatments C1 and C2), the effect of lime addition on organic matter content was not significant, whereas when the amount of lime added was higher (treatment C3), the organic matter content was significantly reduced, most likely due to a dilution effect associated with the addition of more lime.

3.2.3. Effects on Soil Substrate Nutrients. The effects of conditioning the tailings with lime and fertilizer on the soil substrate nutrients are shown in Figure 3 . There were highly significant differences $(P<0.01)$ in total $\mathrm{N}$ and available $\mathrm{N}$ among the treatments. Compared to the CK treatment, soil conditioning with lime and fertilizer reduced the total $\mathrm{N}$ content by $58.14 \%, 60.47 \%$, and 58.14 , and the available $\mathrm{N}$ content by $86.10 \%, 84.96 \%$, and $81.92 \%$ in treatments $\mathrm{C} 1$, $\mathrm{C} 2$, and $\mathrm{C} 3$, respectively; however, none of the differences in total $\mathrm{N}$ and available $\mathrm{N}$ among treatments $\mathrm{C} 1, \mathrm{C} 2$, and C3 were significant $(P>0.05)$. The total $\mathrm{N}$ contents of the CK treatment and treatment $\mathrm{C} 1$ were $0.43 \mathrm{~g} / \mathrm{kg}$ and $0.18 \mathrm{~g} /$ $\mathrm{kg}$, respectively, and the difference was $0.25 \mathrm{~g} / \mathrm{kg}$ or $250.00 \mathrm{mg} / \mathrm{kg}$; the corresponding available $\mathrm{N}$ contents were $288.70 \mathrm{mg} / \mathrm{kg}$ and $40.13 \mathrm{mg} / \mathrm{kg}$, respectively, with a difference of $248.57 \mathrm{mg} / \mathrm{kg}$. The similarity in total $\mathrm{N}$ and available $\mathrm{N}$ values indicated that the decrease in total $\mathrm{N}$ content was most likely linked to the decrease in available N. The significant decrease in available $\mathrm{N}$ may be associated with the availability of calcium ions from the added lime, as calcium ions can replace $\mathrm{NH}_{4}{ }^{+}$adsorbed by the soil for crop uptake and utilization [17]. Owing to the poor water and fertilizer retention capacity of rare earth tailings, the displaced $\mathrm{NH}_{4}^{+}$ may have been lost from the soil, accounting for the significant decrease in available $\mathrm{N}$ after improvement of the rare earth tailings.

Regarding $\mathrm{P}$ content in the tailings in response to soil conditioning, there was no significant difference in total $\mathrm{P}$ among the treatments (Figure 3; $P>0.05$ ); however, the total $\mathrm{P}$ content in treatment $\mathrm{C} 1$ was lower by $6.67 \%$ compared to that in the CK treatment. There were significant differences in available $\mathrm{P}$ content among the treatments (Figure 3; $\mathrm{P}<$ 0.05). Compared to the CK treatment, available $P$ was significantly lower by $43.13 \%, 39.90 \%$, and $16.80 \%$ in treatments $\mathrm{C} 1, \mathrm{C} 2$, and $\mathrm{C} 3$, respectively, indicating an impact of added lime. In addition, the available $\mathrm{P}$ was significantly lower in treatments $\mathrm{C} 1$ and $\mathrm{C} 2$ compared to that in treatment $\mathrm{C} 3$.

Lime combined with fertilizer had no significant effect on total $\mathrm{K}(P>0.05)$ but a highly significant effect on available $\mathrm{K}(P<0.01)$ among the tailing's treatments (Figure 3$)$. Compared to the $\mathrm{CK}$ treatment, the treatments with lime combined with fertilizer all showed a highly significant reduction in available $\mathrm{K}$ of $27.58 \%, 33.35 \%$, and $30.85 \%$ in treatments $\mathrm{C} 1, \mathrm{C} 2$, and $\mathrm{C} 3$, respectively.

3.3. Growth Characteristics and Rare Earth Element Content of Chinese Cabbage. The effects of lime combined with fertilizer on the growth characteristics and REE content of Chinese cabbage are shown in Table 3. There were significant differences $(P<0.05)$ in plant height and fresh weight among the treatments. Chinese cabbage did not grow in the control soil, but it grew in all the treatment soils conditioned with lime and fertilizer. There was no significant difference in growth characteristics in treatment C2 compared to those in treatment $\mathrm{C} 1$; however, treatment $\mathrm{C} 3$ produced Chinese cabbage plants with $38.26 \%$ and $17.86 \%$ lower height and fresh weight, respectively, compared to the other treatments. There was a significant difference $(P<0.05)$ in the total amount of REEs in the Chinese cabbage plants among the treatments. Compared to that in treatment $\mathrm{C} 1$, the REE content in Chinese cabbage plants was reduced by $35.06 \%$ and $72.67 \%$ in treatments $\mathrm{C} 2$ and $\mathrm{C} 3$, respectively. 

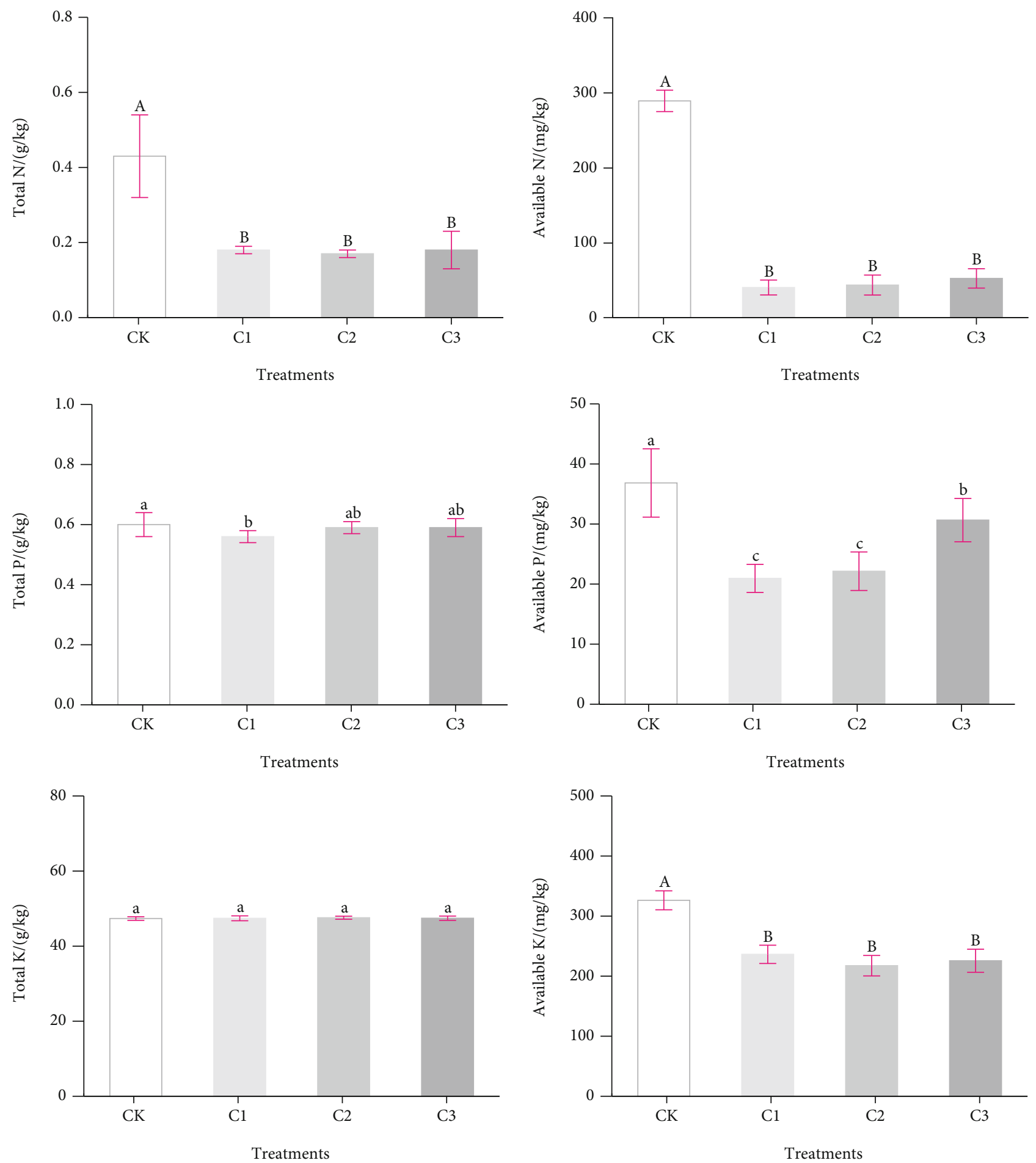

Figure 3: Effect of lime combined with fertilizer on soil fertility of rare earth mine tailings. CK: fertilizer $\left(0.20 \mathrm{~g} \mathrm{~N}, 0.30 \mathrm{~g} \mathrm{P}_{2} \mathrm{O}_{5}\right.$, and $0.30 \mathrm{~g}$ $\mathrm{K}_{2} \mathrm{O}$ per kg of tailings); C1: fertilizer $+10 \mathrm{~g} / \mathrm{kg}$ lime; C2: fertilizer $+25 \mathrm{~g} / \mathrm{kg}$ lime, and C3: fertilizer $+50 \mathrm{~g} / \mathrm{kg}$ lime.

The REE content of the Chinese cabbage plants was dominated by four elements, namely, La, Ce, $\mathrm{Nd}$, and $\mathrm{Y}$, and the contents of the four REEs in all treatments accounted for over $71 \%$ of the total amount of REEs in the plant tissues. Significant differences $(P<0.05)$ were observed among the different treatments for the REEs: $\mathrm{La}, \mathrm{Ce}, \mathrm{Nd}$, and $\mathrm{Y}$ in the Chinese cabbage plants.

\section{Discussion}

Correlation analysis of the basic physicochemical properties and heavy metal content of the rare earth tailings soil substrate showed evidence of soil degradation, particularly desertification, acidification, nutrient depletion, and heavy metal contamination, which concurred with the findings of 
TABLE 3: Growth characteristics and rare earth element content of Chinese cabbage grown in rare earth mine tailings conditioned with a combination of fertilizer and lime.

\begin{tabular}{lccccccc}
\hline Treatment & Height $(\mathrm{cm})$ & Fresh weight $(\mathrm{g} / \mathrm{plant})$ & EREEs $(\mathrm{mg} / \mathrm{kg})$ & $\mathrm{La}(\mathrm{mg} / \mathrm{kg})$ & $\mathrm{Ce}(\mathrm{mg} / \mathrm{kg})$ & $\mathrm{Nd}(\mathrm{mg} / \mathrm{kg})$ & $\mathrm{Y}(\mathrm{mg} / \mathrm{kg})$ \\
\hline $\mathrm{CK}$ & - & - & - & - & - & - & - \\
$\mathrm{C} 1$ & $6.90 \mathrm{a}$ & $1.12 \mathrm{a}$ & $58.36 \mathrm{a}$ & $12.15 \mathrm{a}$ & $12.52 \mathrm{a}$ & $9.84 \mathrm{a}$ & $12.00 \mathrm{a}$ \\
$\mathrm{C} 2$ & $5.67 \mathrm{ab}$ & $1.08 \mathrm{a}$ & $37.9 \mathrm{~b}$ & $7.76 \mathrm{~b}$ & $9.07 \mathrm{~b}$ & $6.07 \mathrm{~b}$ & $5.98 \mathrm{~b}$ \\
$\mathrm{C} 3$ & $4.26 \mathrm{~b}$ & $0.92 \mathrm{~b}$ & $15.95 \mathrm{c}$ & $4.42 \mathrm{c}$ & $1.48 \mathrm{c}$ & $3.24 \mathrm{c}$ & $2.23 \mathrm{c}$ \\
\hline
\end{tabular}

-: no data; CK: fertilizer $\left(0.20 \mathrm{~g} \mathrm{~N}, 0.30 \mathrm{~g} \mathrm{P}_{2} \mathrm{O}_{5}\right.$, and $0.30 \mathrm{~g} \mathrm{~K}_{2} \mathrm{O}$ per kg of tailings); C1: fertilizer + $10 \mathrm{~g} / \mathrm{kg}$ lime; C2: fertilizer $+25 \mathrm{~g} / \mathrm{kg}$ lime; $\mathrm{C} 3$ : fertilizer $+50 \mathrm{~g} / \mathrm{kg}$ lime.

previous studies $[3,4]$. Notably, the metal contamination of the ionic rare earth mine tailings was attributed to contamination by REEs rather than by common soil heavy metals. Although Codex Alimentarius Commission (CAC), Australia, New Zealand, Japan, the United States, and China have not regulated the content of REEs in food, recent studies have shown that water or soil containing high levels of rare earth heavy metals can eventually enter the human body through the food chain, and excessive intake of REEs poses a risk to human health $[18,19]$. Therefore, for the purpose of rare earth tailings restoration, the problem of rare earth element contamination should be highlighted in addition to the problem of contamination by conventional heavy metal pollutants.

Chinese cabbage did not grow in the tailings treated with fertilizer only (CK), whereas it grew in the treatments conditioned with a combination of fertilizer and lime $(\mathrm{C} 1, \mathrm{C} 2$, and C3). The limitation of cabbage growth could be attributed to the strong acidity (Table 1) of rare earth tailings in the CK. The optimal soil $\mathrm{pH}$ for lettuce growth is between $\mathrm{pH} 6.0$ and 7.5 for cabbage [20]. The soil pH in the CK was below 4.5 (Table 1), which was not conducive to the growth of cabbage. This finding also suggests that the nutrient deficiency in the tailings could not be improved by the addition of fertilizer alone (Figure 3), whereas a combination of lime and fertilizer supported Chinese cabbage growth, most likely because it alleviated soil acidification, heavy metal contamination, desertification, and nutrient depletion, all at the same time. For example, lime increases the concentration of calcium ions in the soil, and calcium ions replace the hydrogen and aluminum ions adsorbed by the soil. These interact with the alkali in the lime, ultimately raising the soil $\mathrm{pH}$ and reducing soil acidification [21].

The content of REEs in the Chinese cabbage tissues significantly decreased with increasing lime dosage, suggesting that the lime significantly inhibited the activity of the REEs. The lime may have significantly increased the soil $\mathrm{pH}$, which could have facilitated the precipitation of heavy metals, as well as increasing the negative charge on the surface of the soil colloids, thereby enhancing the heavy metal adsorption capacity [22]. Calcium ions have an antagonistic effect on heavy metals, and the antagonistic effect increases with increasing lime dosage, which is an important reason for why the addition of lime reduces heavy metal toxicity in soil [23]. Furthermore, the bulk density was significantly reduced by the addition of lime, suggesting that the combination of lime and fertilizer significantly reduced the prob- lem of soil desertification. Previous studies [24, 25] have shown that $\mathrm{Ca}^{2+}$ ions in lime can disperse and flocculate soil particles and promote the formation of soil aggregates. Our results showed that the amount of lime added had an impact on Chinese cabbage growth, where excessive lime was detrimental to growth, and may be related to a significant reduction of organic matter (Figure 2). When the lime application was high (treatment C3), there may have been a dilution effect caused by large amounts of lime that led to a decrease in organic matter content, which could have detrimentally affected Chinese cabbage growth. Excessive lime application is known to cause an increase in free calcium ions, which could lead to an imbalance of soil nutrients (e.g., reduction of organic matter) [17]. This effect may ultimately have undermined Chinese cabbage growth.

In this study, we used lime combined with fertilizer to improve ionic rare earth mine tailings and evaluated the improvement effect on the growth of Chinese cabbage. The best response to conditioning of the tailings was obtained for treatment $\mathrm{C} 1$ (fertilizer $+10 \mathrm{~g} / \mathrm{kg}^{-1}$ ), as determined from the analysis of Chinese cabbage growth and soil property changes, as well as input costs. Our findings showed that the application of conditioner alleviated the problem of soil degradation of ionic rare earth mine tailings. In the present study, there was no CK without any conditioners, and a treatment with only lime. Thus, the main effects of lime and fertilization could not be tested. Hence, further research is needed. Moreover, future research should explore more deeply how to further improve the restoration effect of conditioners by investigating different combinations of conditioners in different proportional relationships.

\section{Conclusion}

The rare earth mine tailings exhibited soil degradation issues, particularly acidification, desertification, nutrient depletion, and REE contamination. Rare earth tailings amended with fertilizer alone (CK treatment) did not support the growth of Chinese cabbage, whereas different amounts of lime applied with the fertilizer (treatments C1, $\mathrm{C} 2$, and $\mathrm{C} 3$ ) resulted in Chinese cabbage growth in the rare earth tailings.

The addition of lime with fertilizer significantly improved the soil physical properties and soil $\mathrm{pH}$ of the rare earth tailings. Moreover, the combination of lime and fertilizer transformed the soil texture of the rare earth tailings from a tight sandy loam to a medium loam. It showed that 
the application of lime and fertilizer can significantly improve the soil desertification and soil acidification of rare earth tailings. In this study, treatment $\mathrm{C} 1$ (fertilizer $+10 \mathrm{~g} / \mathrm{kg}$ ) showed the best effect based on a comprehensive consideration of input costs and improvement effects.

\section{Data Availability}

The data used to support the findings of this study are included within the article.

\section{Conflicts of Interest}

The authors declared no potential conflicts of interest with respect to the research, authorship, and/or publication of this article.

\section{Acknowledgments}

The authors disclosed receipt of the following financial support for the research, authorship, and/or publication of this article. This work is financially supported by Key Research and Development Program of Jiangxi Province, China (No. 20181ACG70006), and the Key Research Foundation of Education Bureau of Jiangxi Province, China (No. GJJ170244).

\section{References}

[1] S. L. Gai, C. Li, P. Yang, and J. Lin, "Recent progress in rare earth micro/nanocrystals: soft chemical synthesis, luminescent properties, and biomedical applications," Chemical Reviews, vol. 114, no. 4, pp. 2343-2389, 2014.

[2] R. Chi, J. Tian, Z. J. Li et al., "Existing state and partitioning of rare earth on weathered ores," Journal of Rare Earths, vol. 23, pp. 756-759, 2005.

[3] Z. Q. Gao and Q. X. Zhou, "Contamination from rare earth ore strip mining and its impacts on resources and eco-environment," Chinese Journal of Ecology, vol. 30, pp. 2915-2922, 2011.

[4] X. Li, Z. B. Chen, and Z. Q. Chen, "Distribution and fractionation of rare earth elements in soil-water system and human blood and hair from a mining area in Southwest Fujian Province, China," Environmental Earth Sciences, vol. 72, no. 9, pp. 3599-3608, 2014.

[5] L. J. Mao, D. W. Mo, J. H. Yang, and C. X. Shi, "Geochemistry of trace and rare earth elements in red soils from the Dongting Lake area and its environmental significance," Pedosphere, vol. 19, no. 5, pp. 615-622, 2009.

[6] W. Y. Wang, Y. Xu, R. Yan, and Z. Zhang, "New insights into ion adsorption type rare-earths mining-bacterial adsorption of yttrium integrated with ammonia nitrogen removal by a fungus," Sustainability, vol. 13, no. 16, p. 9460, 2021.

[7] X. Ligang and X. Meijuan, "Research on the negative externalities evaluation for the development of weathered crust elution-deposited rare earth ores," Advances in Materials Science and Engineering, vol. 2020, Article ID 8130196, 11 pages, 2020.

[8] Q. Zhang, G. Wan, C. Zhou, J. Luo, J. Lin, and X. Zhao, "Rehabilitation effect of the combined application of bamboo biochar and coal ash on ion-adsorption-type rare earth tailings,"
Journal of Soils and Sediments, vol. 20, no. 9, pp. 3351-3357, 2020.

[9] X. Z. Hao, D. Wang, P. Wang, Y. Wang, and D. Zhou, "Evaluation of water quality in surface water and shallow groundwater: a case study of a rare earth mining area in southern Jiangxi Province, China," Environmental Monitoring and Assessment, vol. 188, no. 1, pp. 1-11, 2015.

[10] J. H. Quastel, "Soil conditioners," Annual Review of Plant Physiology, vol. 5, no. 1, pp. 75-92, 1954.

[11] R. Lal, "Restoring soil quality to mitigate soil degradation," Sustainability, vol. 7, no. 5, pp. 5875-5895, 2015.

[12] R. Baumhardt, B. Stewart, and U. Sainju, "North American soil degradation: processes, practices, and mitigating strategies," Sustainability, vol. 7, no. 3, pp. 2936-2960, 2015.

[13] N. S. Bolan, D. C. Adriano, and D. Curtin, "Soil acidification and liming interactions with nutrient and heavy metal transformation and bioavailability," in Advances in Agronomy, pp. 215-272, Academic Press, 2003.

[14] K. N. Palansooriya, S. M. Shaheen, S. S. Chen et al., "Soil amendments for immobilization of potentially toxic elements in contaminated soils: a critical review," Environment International, vol. 134, p. 105046, 2020.

[15] L. F. Yang, C. Li, D. Wang et al., "Leaching ion adsorption rare earth by aluminum sulfate for increasing efficiency and lowering the environmental impact," Journal of Rare Earths, vol. 37, no. 4, pp. 429-436, 2019.

[16] China National Environmental Monitoring Centre, Background Values of Soil Elements in China, Chinese Environmental Science Press, Beijing, 1990.

[17] Y. C. Lei, Acid-base buffering ability of long-term fertilization soil \& red soil improvement with quicklime, Fujian Agricultural and Forest University, Fuzhou, 2010.

[18] B. G. Wei, Y. Li, H. Li, J. Yu, B. Ye, and T. Liang, "Rare earth elements in human hair from a mining area of China," Ecotoxicology and Environmental Safety, vol. 96, pp. 118-123, 2013.

[19] M. Q. Zhuang, L. Wang, G. Wu et al., "Health risk assessment of rare earth elements in cereals from mining area in Shandong, China," Scientific Reports, vol. 7, no. 1, pp. 9772-9777, 2017.

[20] S. Carter, S. Shackley, S. Sohi, T. Suy, and S. Haefele, "The impact of biochar application on soil properties and plant growth of pot grown lettuce (Lactuca sativa) and cabbage (Brassica chinensis)," Agronomy, vol. 3, no. 2, pp. 404-418, 2013.

[21] D. Houle, L. Duchesne, J. D. Moore, M. R. Laflèche, and R. Ouimet, "Soil and tree-ring chemistry response to liming in a sugar maple stand," Journal of Environmental Quality, vol. 31, no. 6, pp. 1993-2000, 2002.

[22] A. Hussain Lahori, Z. Zhang, Z. Guo et al., "Potential use of lime combined with additives on (im)mobilization and phytoavailability of heavy metals from $\mathrm{Pb} / \mathrm{Zn}$ smelter contaminated soils," Ecotoxicology \& Environmental Safety, vol. 145, pp. 313-323, 2017.

[23] S. Qin, H. Liu, Z. Nie et al., "Toxicity of cadmium and its competition with mineral nutrients for uptake by plants: a review," Pedosphere, vol. 30, no. 2, pp. 168-180, 2020.

[24] K. Y. Chan and D. P. Heenan, "Effect of lime $\left(\mathrm{CaCO}_{3}\right)$ application on soil structural stability of a red earth," Soil Research, vol. 36, no. 1, pp. 73-86, 1998.

[25] R. J. Haynes and R. Naidu, "Influence of lime, fertilizer and manure applications on soil organic matter content and soil physical conditions: a review," Nutrient Cycling in Agroecosystems, vol. 51, no. 2, pp. 123-137, 1998. 